\title{
Chemical and physical properties of an anthropogenic dark earth soil from Bragança, Para, Eastern Amazon
}

\author{
Luma Castro de SOUZA ${ }^{1}$, Herdjania Veras de LIMA $^{2}$, Sueli RODRIGUES ${ }^{*}$, Dirse Clara KERN³ \\ Álvaro Pires da SILVA 4 , Jorge Luiz PICCININ ${ }^{5}$ \\ ${ }^{1}$ Universidade Estadual Paulista "Júlio de Mesquita Filho", Department of Soils and Fertilizers, ZIP 14884 900, Jaboticabal, São Paulo, Brazil. \\ ${ }^{2}$ Universidade Federal Rural da Amazônia, Institute of Agricultural Science, Tancredo Neves Av. 2501, ZIP 66077 901, Belém, Pará, Brazil. \\ ${ }^{3}$ Museu Paraense Emílio Goeldi, Department of Earth and Ecology Science, ZIP 66077 530, Belém, Pará, Brazil. \\ ${ }^{4}$ Universidade de São Paulo, Department of Soil Science, Pádua Dias Av. 11, ZIP 13418 900, Piracicaba, São Paulo, Brazil. \\ ${ }^{5}$ Universidade Estadual Paulista "Júlio de Mesquita Filho", Institute of Geosciences, 24th Avenue 1515, ZIP 13506 900, Rio Claro, São Paulo, Brazil. \\ *Corresponding author: rodsueli@gmail.com
}

\begin{abstract}
Although anthropogenic dark earth (ADE) is generally found in non-floodable land, it also occurs on floodplains but, there is no information about the chemical and physical characteristics of $\mathrm{ADE}$ in this environment. In this study, we propose to check the hypothesis that a Gleysol, classified as ADE, presents improved chemical and physical conditions than an adjacent soil, no anthropogenic. Thus, the objective of this study was to characterize the chemical and physical properties of the top layer of two ADE profiles in a Gleysol and compare them with an adjacent soil. Samples were taken from two areas classified as ADE in Bragança, Pará State, Brazil, at the "Jabuti" archaeological site, and from an adjacent non-anthropogenic site. Disturbed and undisturbed soil samples were collected at the soil depth of $0.05-0.10 \mathrm{~m}$ for chemical $(\mathrm{pH}$, potential acidity, exchangeable cations, and soil organic carbon) and physical (soil particle size distribution, particles density, water retention curve, total porosity, microporosity, macroporosity, and bulk density) analysis. The two areas of ADE in a Gleysol, showed improved soil chemical properties compared to the adjacent soil, particularly in relation to phosphorus and calcium levels that contributed to higher cation exchange capacity which, in turn, was positively related to organic carbon content. Changes in soil physical properties were less noticeable but both areas of ADE presented higher water retention capacity, particularly at low tension. The improved conditions of the ADE soil under Gleysols shows that these areas are adequate for soil cultivation, especially with plants adapted to floodplain.
\end{abstract}

KEYWORDS: Anthropic horizon, Soil organic carbon, Soil quality, Floodplain soils

\section{Propriedades físicas e químicas de Terra Preta Antropogênica em Bragança, Pará, Amazônia Oriental}

\begin{abstract}
RESUMO
Embora as terras pretas antropogênicas (TPA) geralmente são encontradas em áreas de terra firme, elas também ocorrem em áreas e várzeas, mas, não há informaçóes sobre as características químicas e físicas de TPA neste ambiente. Neste estudo, nós propomos verificar a hipótese de que um Gleissolo, classificado como TPA, apresenta melhores condiçóes químicas e físicas do que o solo adjacente, não antropogênico. Assim, o objetivo do estudo foi caracterizar as propriedades químicas e físicas da camada superficial de dois perfis de TPA em um Gleissolo e compará-los com um solo adjacente. Amostras de solo foram coletadas em duas áreas classificadas como TPA em Bragança, Estado do Pará, Brasil, no sítio arqueológico "Jabuti” e em uma área adjacente não antropogênica. Amostras de solo com estrutura deformada e indeformada foram coletadas na profundidade de 0,05-0,10 m para análises químicas ( $\mathrm{pH}$, acidez potencial, cátions trocáveis, e carbono orgânico do solo) e físicas (distribuição do tamanho das partículas do solo, densidade de partículas, curva de retenção de água, porosidade total, microporosidade, macroporosidade e densidade do solo). As duas áreas de TPA em Gleissolo, apresentaram melhores propriedades químicas comparadas com o solo adjacente, principalmente em relação aos níveis de fósforo e cálcio que contribuíram para a maior capacidade de troca catiônica que, por sua vez, foi positivamente relacionada com o conteúdo de carbono orgânico. Mudanças nas propriedades físicas do solo foram menos pronunciadas, mas as duas áreas de TPA exibiram maior capacidade de retençáo de água, sobretudo em baixa tensão.
\end{abstract}

PALAVRAS-CHAVE: Horizonte antropogênico, Carbono orgânico do solo, Qualidade do solo, Solos de várzea. 


\section{INTRODUCTION}

A range of different soil classes is found in the Amazon Basin, each one with distinct properties. However, they are generally represented by soils highly weathered, with low fertility and low soil organic matter (SOM) such as clayey Ferralsols or sandy Podzols (Lehmann et al. 2003; Teixeira et al. 2009). The activities of indigenous populations in the pre-Columbian period have created anthropogenic horizons in some soil classes that present contrasting properties compared to those of adjacent soils. Soils with such horizons are known as anthropogenic dark earths (ADE - Terra Preta de Indio), and they are present in a range of soil classes and landscapes with dimensions varying from one hectare to several square kilometers.

In the Brazilian Amazon, horizons that are typical of ADE have already been described for Ferralsols, Acrisols, Arenosols, Podzols, Luvisols, Nitisols, and Cambisols, classified according to WRB (World Reference Base for Soil Resources) soil classification system (Lehmann et al. 2003; Woods et al. 2009; Teixeira et al. 2009). In addition, the chemical and physical characteristics of these soils have been also reported in several publications (Falcão and Borges 2006; Moreira et al. 2009; Santos et al. 2013 b). However, such descriptions have mainly been associated with Oxisols and occasionally with other soil classes such as Inceptsol, Ultisol, and Entisols, these classified according to Soil Taxonomy classification system.

In general, the chemical and physical characteristics of the soils associated with ADE are improved, indicating that the fertility and structure of the poor soils, from Amazon, may be greatly enhanced. For example, ADE soils have a higher nutrient content and thus promote a better soil fertility. In addition, the soil organic matter (SOM) content in $\mathrm{ADE}$ is usually higher, thereby increasing the potential cation exchange capacity and base saturation (Glaser $e t$ al. 2001; Lehmann et al. 2003). High amounts of SOM in ADE also influence soil color, structure, and hydraulic properties, and soil bulk density values are commonly lower in the anthropogenic top horizons in ADE (Lehmann et al. 2003). $\mathrm{ADE}$ also appears to be a very resilient soil that is able to retain its good physical qualities, even under intensive use (Teixeira et al. 2009).

Although ADE soils occur in a range of soil classes, there is limited information on different types of soils, particularly for those from floodplains. Despite ADE is generally found in non-floodable land, it also occurs on floodplains covered by sediments or land that has been destroyed by the lateral movements of rivers (Teixeira et al. 2009). Due the high precipitation in the Amazon region, there are large areas of wetland soils and Gleysols are the predominant soil class and, unlike Ferralsols, these soils usually have no limitations with regard to natural fertility. Gleysols are hydromorphic soils with a gley horizon and are the most common lowland soil class in the Amazon region. Therefore, because of their widespread occurrence in the region, effective management of such soils is a valuable alternative for increasing agricultural production.

Despite wetness is a limitation for the use and management of Gleysols, adapted plants are commonly used, like rice and, in the Amazon region, the açaí palm (Euterpe oleracea Mart.) has been cultivated. So, determining the properties of ADE in Gleysols can provide important information about the potential use of these soils. Since there is no available information about ADE properties associated with Gleysols; in this study, we propose to check the hypothesis that a Gleysol, classified as ADE, presents improved chemical and physical conditions than an adjacent soil, no anthropogenic. Thus, the objective of this study was to characterize the chemical and physical properties of the top layer of two ADE profiles in a Gleysol and compare them with an adjacent soil.

\section{MATERIALS AND METHODS}

\section{Site description}

In this study, soil samples obtained from two areas from "Jabuti" archaeological site, classified as anthropogenic dark earths (ADE), and an adjacent area, no anthropogenic, were studied. Both areas are located in Bragança, Pará state, Brazil (46 $40^{\circ} 19.8^{\prime \prime} \mathrm{W}$; $\left.0^{\circ} 55^{\prime} 39.5^{\prime \prime} \mathrm{S}\right)$, situated on the bank of the river Caeté. This region is located in the high plains of Bragantina Peninsula, overlying sedimentary rocks from Barreiras geological formation. More details about the site description can be found in Silveira et al. (2011). The climate is classified as Aw according to Köppen classification, with a mean annual temperature and precipitation of $25^{\circ} \mathrm{C}$ and 2,500 to $3,000 \mathrm{~mm}$, respectively, a dry season from August to December, and a rainy season from January to July, when over $90 \%$ of total annual precipitation occurs (Moraes et al. 2005). The relief is plan to smooth undulated. According to the Brazilian classification, the soil is a Gleissolo (Santos et al. 2013 a). Morphological descriptions of the three sites are presented in Table 1.

The Jabuti site was registered in 2008 as a ceramic archaeological site, housing type, with fragments of ceramic in surface and depth (Silveira et al. 2011). Archaeological materials in the area are mainly composed by ceramic fragments, lytic artefacts chipped, charcoal, seeds, animal bones and shells; dating analysis indicates that the site was occupied for at least 2,900 years before present (Silveira et al. 2011). Currently, the vegetation consists of secondary forests with a large number of palm trees, particularly the species Maximiliana regia and Orbignya oleifera. 
Table 1. Morphological descriptions of the archaeological dark earths (ADE) and the adjacent (ADJ) soil.

\begin{tabular}{|c|c|c|c|c|c|c|}
\hline Horizon & $\begin{array}{l}\text { Depth } \\
\mathrm{cm}\end{array}$ & $\begin{array}{l}\text { Colour } \\
\text { (wet) }\end{array}$ & Texture & $\begin{array}{l}\text { Consistency } \\
\text { (humid) }\end{array}$ & Drainage & Structure \\
\hline \multicolumn{7}{|c|}{ Gleysol - ADE 1} \\
\hline A & $0-16$ & 10YR 3/1 & sandy & loose & well & distinct, weak, simple (20\% crumb) \\
\hline A1 & $16-42$ & 10YR 2/1 & sandy & loose & well & low distinct, weak, simple (20\% crumb) \\
\hline A2 & $42-68$ & 10YR 2/1 & sandy & loose & well & massive \\
\hline$A B$ & $68-90$ & $\begin{array}{l}\text { 10YR 3/1 } \\
\text { 10YR } 7 / 1\end{array}$ & sandy & loose & moderately & massive \\
\hline BA & $90-124$ & $\begin{array}{l}\text { 10YR } 7 / 1 \\
\text { 10YR } 4 / 1\end{array}$ & sandy & loose & moderately & massive \\
\hline $\mathrm{Bg}$ & $>124$ & $6 / 10 Y$ & sandy & loose & poorly & massive \\
\hline \multicolumn{7}{|c|}{ Gleysol - ADE 2} \\
\hline A & $0-12$ & 10YR 2/1 & sandy & loose & well & distinct, weak, simple (20\% crumb) \\
\hline A1 & $12-29$ & 10YR 2/1 & sandy & loose & well & low distinct, weak, massive \\
\hline A2 & $29-43$ & 10YR 3/1 & sandy & loose & well & massive \\
\hline$A B$ & $43-58$ & $\begin{array}{c}\text { 10YR 3/1 } \\
6 / 10 Y\end{array}$ & sandy & loose & moderately & massive \\
\hline $\mathrm{Bg}$ & $>58$ & $6 / 10 Y$ & sandy & loose & poorly & massive \\
\hline \multicolumn{7}{|c|}{ Gleysol - ADJ } \\
\hline A & $0-18$ & 7.5YR 4/1 & sandy & loose & well & distinct, weak, simple \\
\hline A1 & $18-28$ & 7.5YR 5/1 & sandy & loose & well & low distinct, weak, massive \\
\hline$A B$ & $28-42$ & 7.5YR 6/2 & sandy & loose & moderately & massive \\
\hline BA & $42-60$ & $\begin{array}{c}\text { 10YR } 7 / 2 \\
6 / 10 Y\end{array}$ & sandy & loose & poorly & massive \\
\hline $\mathrm{Bg}$ & $>60$ & $6 / 10 Y$ & sandy & loose & poorly & massive \\
\hline
\end{tabular}

Source: Piccinin (2009)

\section{Soil sampling}

The delimitation of the site was made by opening holes using an auger to verify the presence/absence of ceramic traces, and variation in soil color using the Munsell scale. From these data three areas were selected for sampling: two within the site ( $\mathrm{ADE} 1$ and 2) and an adjacent to the site (ADJ), considered as a control (Silveira et al. 2011). Ten undisturbed samples were collected every $1 \mathrm{~m}$ in a $10 \mathrm{~m}$ transect, using metallic rings of $0.05 \mathrm{~m}$ diameter and height, at a soil depth of 0.05-0.10 m. To decrease biological activity, samples were then stored at $4^{\circ}$ $\mathrm{C}$ until laboratory analysis. Although the thickness of the layer of $\mathrm{ADE}$ of 0.90 and $0.40 \mathrm{~m}$ for ADE 1 and 2, respectively; sampling took place only within the top soil layer, because this is the area in which the greatest physical responses to human activities occurs (Drewry 2006), and where there is greater SOM accumulation and biological activity.

Disturbed samples were also collected at the same depth using an auger, air-dried and sieved through a $2-\mathrm{mm}$ mesh sieve for chemical analysis, soil particle size distribution and particles density.

\section{Determination of chemical parameters}

Soil $\mathrm{pH}$ was determined using a $\mathrm{pH}$-meter by suspending soil at a ratio of 1:1 soil to water, and then with 1:1.25 soil to $\mathrm{KCl}$ solution. Potential acidity $(\mathrm{H}+\mathrm{Al})$ was estimated using $0.5 \mathrm{~mol} \mathrm{~L}^{-1}$ calcium acetate at $\mathrm{pH} 7.0$, and exchangeable cations $(\mathrm{Ca}, \mathrm{Mg}$, and $\mathrm{Al})$ were extracted using the chloride method. Soil potassium (K) and phosphorus (P) were extracted with Mehlich-1 solution, and soil organic carbon (OC) was determined in accordance with the Walkley-Black method, using wet oxidation with dichromate.

\section{Determination of physical parameters}

Soil particle size distribution was determined using the pipette method after dispersion in a mixer with hexametaphosphate and digestion of organic matter with $\mathrm{H}_{2} \mathrm{O}_{2}$ (Gee and Bauder 1986). A gas pycnometer was used for particle density analysis (model Accupyc 1330, Micromeritics, Norcross, GA, USA).

Soil water retention curves were determined in the undisturbed samples using a tension table for water potentials of $-10,-30,-60$, and $-100 \mathrm{hPa}$, and a pressure plate apparatus 
for $-250,-500,-1,000 ;-3,000$, and $-15,000 \mathrm{hPa}$. The relationship between water potential and soil water content was determined using the van Genutchen model (1980).

Bulk density was calculated from dry soil weight values $\left(105^{\circ} \mathrm{C} ; 48 \mathrm{~h}\right)$ and ring volume data (Blake and Hartge 1986), and soil total porosity was calculated from soil bulk density and particle density values. Microporosity was considered by determining the water content of soil samples submitted to tension of $-60 \mathrm{hPa}$, and macroporosity was calculated by the difference between total porosity and microporosity. The field capacity and permanent wilting point were estimated by soil moisture in tensions of -100 and $-15,000 \mathrm{hPa}$, respectively, and available water was determined as the difference between field capacity and permanent wilting point.

\section{Statistical Analysis}

Data were evaluated using the ANOVA procedure with SAS software (Statistical Analysis System, version 9.2). Probability level was significant at $\mathrm{p} \leq 0.05$, and Pearson correlation coefficients were calculated to characterize the relationships between soil chemical and physical parameters.

\section{RESULTS}

The surface anthropogenic horizons within Gleysols showed significant changes in soil chemical properties (Table 2). The $\mathrm{pH}$ is an index used to determine soil potential acidity and differed among the areas ranging from very acidic $(4.5-5.0)$ to extremely acidic $(<4.5)$ in the three soils. Samples from ADJ and ADE 2 had high acidity $(\approx \mathrm{pH} 4$; Table 2), which resulted in a high level of exchangeable Al. However, $\mathrm{ADE} 1$ was less acidic with a $\mathrm{pH}_{\mathrm{H} 2 \mathrm{O}}$ of 5.0; this slight incremental caused a significant decrease in the level of exchangeable Al. Falcão et al. (2009) reported that ADE does not generally present problems with respect to aluminum toxicity with values ranging from 1.60 to $0.01 \mathrm{cmol} \mathrm{kg}^{-1}$. This range is below of the values observed in $\mathrm{ADJ}$ and $\mathrm{ADE}$ 2 that also presented $\mathrm{pH}$ below 5.0. In fact, when the soil $\mathrm{pH}$ is below 5.0, soluble $\mathrm{Al}$ is almost certainly a problem whereas $\mathrm{pH}$ values between 5.0 and 5.5 is likely a small problem (Ritchie 1995); although high Al content not always is toxic for plants especially for soils with high organic matter content (Hernández-Soriano 2012).

With the exception of potassium $\left(\mathrm{K}^{+}\right)$, ADE 1 and 2 contained higher amounts of nutrients compared to ADJ (Table 2); there was significant enrichment of total $\mathrm{P}$ and $\mathrm{Ca}$ in $\mathrm{ADE} 1$ and 2 relative to $\mathrm{ADJ}$, and $\mathrm{Mg}$ was slightly increased, particularly in ADE 2. Furthermore, the anthropic surface horizons in ADE 1 and $\mathrm{ADE} 2$ presented an exchangeable Ca content that was 35 and 23 times greater than ADJ, respectively, and for exchangeable $\mathrm{Mg}$ the increase was 2.7 and 1.5 times, respectively (Table 2). Suitable levels of $\mathrm{K}$ in soil were from 0.16 to $0.30 \mathrm{cmol} \mathrm{kg}^{-1}$ (Alcarde 1988), and therefore the amounts of $\mathrm{K}$ in $\mathrm{ADJ}$ and $\mathrm{ADE} 1$ and 2 are considered adequate for plant growth; there were no significant differences in values among the areas.

The capacity of exchangeable cations (CEC), the sum of bases $(\mathrm{SB})$, and base saturation $(\mathrm{V})$ were also increased in $\mathrm{ADE}$ horizons compared to the surface samples of ADJ (Table 2). $\mathrm{CEC}$ was low in $\mathrm{ADJ}$, but was increased by 4 and 2.5 times in $\mathrm{ADE} 1$ and $\mathrm{ADE} 2$, respectively. This increase in CEC is related to the positive relationship with the $\mathrm{OC}$ content, as shown in Figure 1.

There were also differences in some physical properties of the surface layers of ADE 1 and 2 compared to the ADJ soil. Firstly, soil color differed between samples (Table 1), and at the depth evaluated it ranged from very dark gray (10YR 3/1) for $\mathrm{ADE} 1$, black (10YR 2/1) for ADE 2, and dark gray (7.5YR 4/1) for ADJ. In relation to particle size distribution, the soils of the three areas were primarily composed of sand size particles (Table 3).

Particles density and soil bulk density were influenced by the higher OC content in ADE 2 only, showing a reduction in both properties (Table 3). The low bulk density in this area is related to a higher porosity, as the soil porosity is composed almost exclusively of micropores. There were no differences in relation to macroporosity among the areas; the high microporosity in ADE 2 also resulted in increased soil water retention (Table 3; Figure 2).

The soil water contents (Figure 2) were in agreement with the $\theta_{\text {sat }}$ and $\theta_{\text {res }}$ (Table 4$)$, i.e. greater water holding capacity

Table 2. Soil chemical properties of two Amazonian Dark Earths (ADE1 and ADE2) and an adjacent soil (ADJ) at 0.05-0.10 m depth.

\begin{tabular}{|c|c|c|c|c|c|c|c|c|c|c|c|c|}
\hline \multirow{2}{*}{ Areas } & \multicolumn{2}{|c|}{$\mathrm{pH}$} & $P$ & $\mathrm{~K}_{+}$ & $\mathrm{Ca}^{2+}$ & $\mathrm{Mg}^{2+}$ & $\mathrm{Al}^{3+}$ & $\mathrm{H}+\mathrm{Al}$ & $\mathrm{S}^{(1)}$ & $\mathrm{CEC}^{(2)}$ & $V^{(3)}$ & $\mathrm{OC}(4)$ \\
\hline & $\mathrm{H}_{2} \mathrm{O}$ & $\mathrm{KCl}$ & $\mathrm{mg} \mathrm{dm}^{-3}$ & \multicolumn{7}{|c|}{$\mathrm{cmol}_{\mathrm{c}} \mathrm{dm}^{-3}$} & $\%$ & $\mathrm{~g} \mathrm{~kg}^{-1}$ \\
\hline ADJ. & $4.2 \mathrm{~b}$ & $3.0 \mathrm{c}$ & $1.48 \mathrm{c}$ & $0.24 a$ & $0.67 \mathrm{c}$ & $1.55 \mathrm{c}$ & $2.25 b$ & $11.69 \mathrm{c}$ & 2.46 & 14.2 & 17 & $37.6 \mathrm{~b}$ \\
\hline ADE1 & $5.0 \mathrm{a}$ & $4.3 a$ & $17.41 a$ & $0.18 \mathrm{a}$ & $24.07 a$ & $4.20 \mathrm{a}$ & $0.77 \mathrm{c}$ & $13.43 b$ & 28.45 & 41.9 & 68 & $55.5 a$ \\
\hline ADE2 & $4.0 \mathrm{c}$ & $3.9 b$ & $8.45 b$ & $0.17 a$ & $15.47 b$ & $2.40 \mathrm{~b}$ & $3.90 \mathrm{a}$ & $15.36 a$ & 18.04 & 33.4 & 54 & $59.5 a$ \\
\hline
\end{tabular}

(1)S: sum of bases; (2) $\mathrm{CEC}$ : cation exchange capacity at $\mathrm{pH} 7,0$; ${ }^{(3)} \mathrm{V}$ : base saturation; ${ }^{(4)} \mathrm{OC}$ : soil organic carbon 


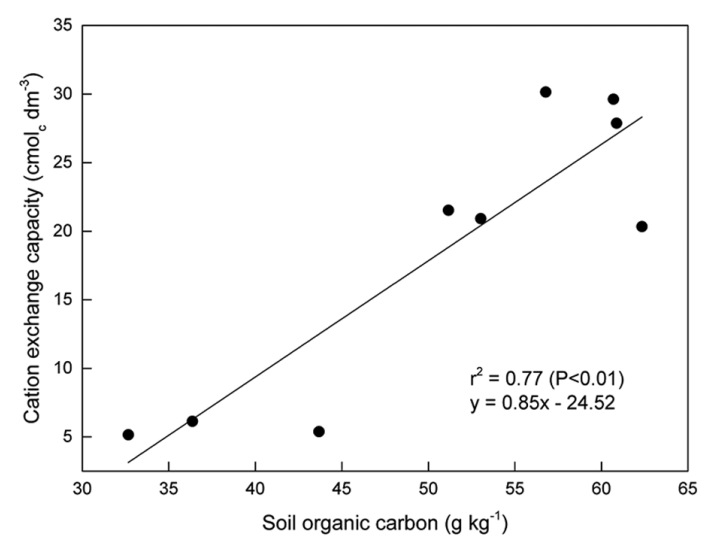

Figure 1. Cation exchange capacity as influenced by soil organic carbon contents.

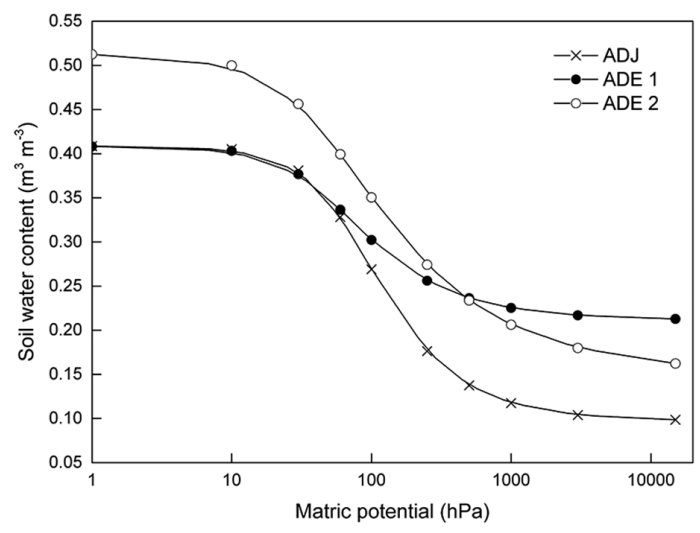

Figure 2. Soil water retention curves of two Amazonian Dark Earths (ADE1 and ADE2) and an adjacent soil (ADJ) at 0.05-0.10 m depth.

Table 3. Soil physical properties of two Amazonian Dark Earths (ADE1 and ADE2) and an adjacent soil (ADJ) at 0.05-0.10 m depth.

\begin{tabular}{lccc}
\hline Soil attributes & ADJ & ADE 1 & ADE 2 \\
\hline Sand $\left(\mathrm{g} \mathrm{kg}^{-1}\right)$ & 815.49 & 678.62 & 644.70 \\
\hline Silt $\left(\mathrm{g} \mathrm{kg}^{-1}\right)$ & 132.01 & 162.83 & 170.89 \\
Clay $\left(\mathrm{g} \mathrm{kg}^{-1}\right)$ & 52.50 & 158.55 & 184.41 \\
Particle density $\left(\mathrm{Mg} \mathrm{m}^{-3}\right)$ & $2.58 \mathrm{a}$ & $2.55 \mathrm{a}$ & $2.51 \mathrm{~b}$ \\
Bulk density $\left(\mathrm{Mg} \mathrm{m}^{-3}\right)$ & $1.55 \mathrm{a}$ & $1.48 \mathrm{a}$ & $1.28 \mathrm{~b}$ \\
Macroporosity $\left(\mathrm{m}^{3} \mathrm{~m}^{-3}\right)$ & $0.05 \mathrm{a}$ & $0.06 \mathrm{a}$ & $0.08 \mathrm{a}$ \\
Microporosity $\left(\mathrm{m}^{3} \mathrm{~m}^{-3}\right)$ & $0.35 \mathrm{~b}$ & $0.36 \mathrm{ab}$ & $0.41 \mathrm{a}$ \\
\hline Total porosity $\left(\mathrm{m}^{3} \mathrm{~m}^{-3}\right)$ & $0.40 \mathrm{~b}$ & $0.42 \mathrm{~b}$ & $0.49 \mathrm{a}$ \\
Available water $\left(\mathrm{m}^{3} \mathrm{~m}^{-3}\right)$ & $0.17 \mathrm{a}$ & $0.15 \mathrm{a}$ & $0.18 \mathrm{a}$ \\
\hline
\end{tabular}

Table 4. Parameters of soil water retention curves fitted by van Genuchten equation (van Genuchten 1980) for two Amazonian Dark Earths (ADE1 and ADE2) and an adjacent soil (ADJ) at 0.05-0.10 $\mathrm{m}$ depth.

\begin{tabular}{lccccc}
\hline \multirow{2}{*}{ Areas } & \multicolumn{2}{c}{$\theta_{\text {sat }} \theta_{\text {res }}$} & $\alpha$ & $\mathrm{n}$ & $R^{2}$ \\
\cline { 2 - 3 } & \multicolumn{2}{c}{$\mathrm{m}^{3} \mathrm{~m}^{-3}$} & & & \\
\hline ADJ. & 0.409 & 0.097 & 0.015 & 2.010 & 0.86 \\
ADE 1 & 0.408 & 0.211 & 0.022 & 1.862 & 0.73 \\
ADE 2 & 0.513 & 0.151 & 0.024 & 1.596 & 0.90 \\
\hline
\end{tabular}

$\theta_{\text {sat }}=$ saturated water content, $\theta_{\text {res }}=$ residual water content, $\alpha$ and $n=$ empirical parameters which describe the shape of the water retention curve.

for ADE 2 at saturation and higher residual water content for ADE 1.

Although ADE 2 had a higher micro and total porosity compared to $\mathrm{ADJ}$, there was not such a significant variation between ADE 1 and ADJ. However, in relation to soil water retention, both ADE 1 and 2 retained more water at field capacity (Figure 2, $100 \mathrm{hPa}$ ) and at wilting point $(15,000$ $\mathrm{hPa}$ ), though there was no difference in relation to available water (Table 3).

\section{DISCUSSION}

Only ADE 1 has a higher $\mathrm{pH}$ compared to the ADJ soil. Falcão et al. (2009) reported that a reduced acidic condition is common in $\mathrm{ADE}$, with $\mathrm{pH}$ ranging from 5.2 to 6.4; this is associated with processes that change soil acidity, such as organism respiration and decomposition of organic matter, which are very active in $\mathrm{ADE}$ soils.

The soil $\mathrm{pH}$ in $\mathrm{H}_{2} \mathrm{O}$ was higher than in $\mathrm{KCl}(1.0 \mathrm{~mol}$ $\left.\mathrm{L}^{-1}\right)$ resulting in a negative $\Delta \mathrm{pH}\left(\mathrm{pH}_{\mathrm{H} 2 \mathrm{O}}-\mathrm{pH}_{\mathrm{KC}}\right) ; \Delta \mathrm{pH}$ is an indicative of the balance of soil charges, and negative values indicate a predominantly net negative charge. The $\mathrm{ADJ}$ area showed the greatest negative value of $\Delta \mathrm{pH}(-1.24)$ due to a broader range of $\mathrm{pH}$ values. This amplitude is generally associated with a higher content of exchangeable aluminum $\left(\mathrm{Al}^{3+}\right)$. However, a relationship between $\Delta \mathrm{pH}$ and exchangeable aluminum, which has been observed in other areas of ADE (Campos et al. 2011), was not evident in the areas evaluated in this study.

Samples from ADJ and ADE 2 showed high concentrations of exchangeable Al. Although it is well known that high levels of $\mathrm{Al}$ in soil can be harmful to plants, there are different forms of $\mathrm{Al}$ in soil and not all are harmful. A high Al content is not detrimental to plants in soils that have high organic carbon content, as some of the components of organic matter form complexes with $\mathrm{Al}$ within soil solution, making it unavailable to plants (Hernández-Soriano 2012). For this reason, soluble $\mathrm{Al}$ is not considered to be a problem for such soils, even if they have a low $\mathrm{pH}$. 
Both ADE 1 and ADE 2 had higher amounts of nutrients compared to the ADJ soil. High levels of nutrients are characteristic of ADEs, which usually hold nutrient stocks several times higher than those of the surrounding soil (Costa and Kern 1999; Lehmann et al. 2003). However, not all nutrients were significantly increased in $\mathrm{ADE} 1$ and 2 compared to the ADJ soil (for example, total $\mathrm{P}$ and $\mathrm{Ca}$ were more enriched than $\mathrm{Mg}$ ), but these results were expected as, according to Lehmann et al. (2003), ADE does not necessarily have a high availability of all nutrients essential for plants, and although available $\mathrm{Ca}$ is more strongly enriched in relation to surrounding soils, other nutrients as $\mathrm{K}, \mathrm{Mg}, \mathrm{Fe}$, and $\mathrm{N}$ are not necessarily higher. In this study, the concentration of $\mathrm{Ca}$ was several times higher than that of $\mathrm{K}$; this association of a low concentration of available $\mathrm{K}$ and a high concentration of Ca may establish an unbalanced nutritional status for many plants (Falcão et al. 2009). The higher P content in $\mathrm{ADE} 1$ and 2 is due the composition of the ceramics found in the areas that have high levels of this element; in fact Rodrigues (2014), evaluating the chemical properties of sherds from this archaeological site, using molten materials, related that the level of phosphorus found was higher than those previously identified in ceramic fragments from archaeological sites located in the Amazon, and related this with the sherds mineralogy.

The higher values of $\mathrm{CEC}, \mathrm{SB}$, and $\mathrm{V}$ in $\mathrm{ADE}$ horizons confirm results observed in other areas of ADE, particularly in relation to Oxisols (Cunha et al. 2009; Campos et al. 2011). These results show how soil OC plays an essential role in providing sites for cation exchange. The higher amount of OC in ADEs gives the soil a higher CEC, as reported by others (Zech et al. 1990; Glaser et al. 2001; Lehmann et al. 2003; Glaser 2007). ADE soils have a high pyrogen carbon content, which has a greater specific surface area and greater negative charge density per unit surface area; thus, high CEC values result from the higher charge density per carbon unit (Liang et al. 2006).

A correlation between CEC and soil OC (Figure 1) shows the large participation that OC plays in CEC. The ADE soils in this study had a SOC concentration that was about 1.5 times greater than that of the $\mathrm{ADJ}$ soil. However, it is not only the amount of SOC that is responsible for the high CEC; the quality of the SOC actually has a greater effect. Studies have revealed that SOM in ADE contains higher amounts of carboxylic groups and phenolic groups compared to the surrounding soils, and thus, SOC in ADE has a higher CEC than the SOC in naturally occurring soils (Liang et al. 2006; Zech et al. 1990; Cunha et al. 2009).

The results show that improvements in the soil fertility of anthropogenic soils in our study are comparable to those reported for others anthropogenic soils sites in the Brazilian Amazon (Cunha et al. 2009; Mescouto et al. 2011; Campos et al. 2011). The marked difference in fertility of the anthropogenic (ADE) and non-anthropogenic (ADJ) soils is attributed to accumulation of organic matter, base cations, and other nutrients, in relation to the addition of organic waste (manure, vegetal and animal organic residues, bones) and black carbon from fire management by pre-Columbian civilizations (Kern and Kämpf 1989; Lima et al. 2002). Indeed, the SOC content was higher in the ADE's soils relative to ADJ; the soil organic carbon content of ADE 1 and ADE 2 was $48 \%$ and $58 \%$ higher than that of ADJ, respectively.

Regarding soil physical properties, the color of ADE presented low value; lower values characterize darker soils and are an indication of high SOM content. The effect of fire in causing the dark color is corroborated by the high number of charcoal pieces found in the site. Due incomplete combustion, organic materials become charcoal with a dark black color. Thus, the lowest value (2) at ADE 2 agrees with the larger OC content observed in this area (Tables 1 and 2), where the dark top layer in $\mathrm{ADE}$ is explained by the effects of fire that charred organic matter, resulting in a black color and consequently a lower chroma value.

The characteristics observed in the surface horizon of the archaeological site enabled to classify it as anthropogenic. According to the Brazilian Soil Classification System (SiBCS, Santos et al. 2013 a), the human impacts in soil are distinguished by an anthropic diagnostic horizon, which is described as a horizon formed or modified by land use (habitation or cultivation), or the addition of organic material containing ceramic fragments and/or lithic artifacts, and other organic materials. For ADEs, this anthropic influence is recognized at the $4^{\text {th }}$ hierarchical level, e.g., Anthropic Dystrophic Yellow Latosol (Latossolos Amarelos Distróficos antrópicos), and Anthropic Dystrophic Concretionary Petric Plinthosols (Plintossolos Pétricos Concrecionários Distróficos antrópicos) (Kern and Kämpf 1989). However, such characteristics in Gleysols are only admitted for soils classified as Anthropic Orthic Tiomorphic Gleysols (Gleissolos Tiomórficos Órticos antrópico), which is related to soils modified by mining, road construction, drainage systems, or other forms of soil alteration for non-agricultural purposes. This definition is not applicable to the characteristics of the soil evaluated in this study; therefore, future revisions of SiBCS are suggested and should include the anthropic diagnostic horizon for other soil classes. According to SiBCS, ADE can be found in several soil classes, such as Latosols (Latossolos), Argisols (Argissolos), Cambisols (Cambissolos), Plinthosols (Plintossolos) and Spodosols (Espodossolos). Here, we have evaluated ADE in Gleysol, however, for this soil class there is no designation for features denoting the influence of human activity (such as the presence of artifacts and charcoal). Sombroek et al. (2002) consider that available ADE data do not yet permit a detailed, field relevant and pedologic classification. Thus, developing 
an $\mathrm{ADE}$ classification is a challenge that demands broader expertise and investigation, especially for soil classes where anthropogenic influences are not yet recognized.

For the three areas, the prevailing soil particle size is sand and the soil texture class for ADJ is loamy sand while both ADEs are sandy loam. The role of organic matter in sandy soils is fundamental, particularly due to the dominant mineralogy (generally quartz, kaolinite, iron, and aluminum oxides) that characterizes soils with low fertility. Therefore, in such soils, it is essential to manage all components that affect soil fertility and structure, mainly the SOM.

The larger volume of micropores and total porosity of ADE 2 is due to the higher CO content in the area. Since black carbon is highly porous, its high content in the soil improves a range of physical properties, including micro and total porosity. However, the mechanisms or processes by which carbonized materials influence soil pore size distribution have not been clearly established or demonstrated (Verheijen et al. 2010).

The higher capacity of ADE's to retain soil water is represented in Figure 2, mainly in the dry part of the curve $(>100 \mathrm{hPa})$. The stabilized organic matter in these soils acts like a sponge and is able to absorb many times its weight in water. This is particularly relevant in sandy soils, where the water held by the organic matter makes a difference to the water availability of plants, especially during dry periods.

The OC content for ADE 1 and 2 was not significantly different (Table 2), nevertheless, they did not show the same trends in relation to chemical and physical changes with respect to ADJ. Therefore, likely not only the amount of OM but also the quality is influencing the properties of these soils. However, despite the extent of the changes in the soil properties were not the same in $\mathrm{ADEs}$, both presented a better soil condition than $\mathrm{ADJ}$, with the exception of $\mathrm{pH}_{\mathrm{H} 2 \mathrm{O}}$ (Table 2). Aquino et al. (2014) evaluating the variability of physical attributes in anthropogenic and non-anthropogenic soils have also observed improved conditions for anthropogenic soils in relation to total porosity, microporosity, and soil bulk density, evidencing the better characteristics of these soils.

Although Gleysol is liable to permanent waterlogging or flooding during some period of the year, it can be cultivated with adapted plants as açaí palm. In the State of Pará, areas cultivated with açaí palm are increasing and, since the plant is highly water-demanding Gleysols have a high potential for its cultivation. Our results showed that ADE associated with this soil class presents a higher ability to hold water at low tension, and this behavior may be important for maintaining water availability for plants during the dry season, especially when linked to higher nutrient availability. Although only the soil surface layer was evaluated in this study, our results provide important information about the chemical and physical properties of these soils for use in future research, particularly for work that seeks to improve perspectives for regional farmers through the cultivation of ADE soils.

There are many areas of $\mathrm{ADE}$ that remain unknown or have been little studied. As more soil surveys are conducted in the Amazon, more ADE profiles in Gleysols may be found in the floodplain areas and its assessment should complement the information reported in this study.

\section{CONCLUSIONS}

The two areas of anthropogenic dark earths (ADE 1 and 2 ) in a Gleysol, showed improved soil chemical properties compared to the adjacent soil, particularly in relation to phosphorus and calcium levels that contributed to higher cation exchange capacity which was positively related to organic carbon content. Changes in soil physical properties were less noticeable but both areas of ADE presented higher water retention capacity, particularly at low tension.

\section{ACKNOWLEDGMENTS}

Brazilian National Council for Scientific and Technological Development $(\mathrm{CNPq})$ for granting the master's scholarship of the first author.

\section{REFERENCES}

Alcarde, J.C. 1988. Análise química do sulfato de potássio e magnésio: estudo e simplificação dos procedimentos analíticos. Revista de Agricultura, 63: 265-271.

Aquino, R.E.; Campos, M.C.C.; Oliveira, I.A.; Marques Jr., J.; Silva, D.M.P.; Silva, D.A.P. 2014. Variabilidade espacial de atributos físicos de solos antropogênico e não antropogênico na região de Manicoré, AM. Bioscience Journal, 30: 988-997.

Blake, G.R.; Hartge, K.H. 1986. Bulk density. In: Klute, A. (Ed.). Methods of soil analysis. Part I. Physical and mineralogical methods. 2ed. America Society of Agronomy, Madison, WI, USA, p. 363-375.

Campos, M.C.C.; Ribeiro, M.R.; Souza Jr., V.S.; Filho, M.R.R.; Souza, R.V.C.C.; Almeida, M.C. 2011. Caracterização e classificação de Terras Pretas Arqueológicas na Região do Médio Rio Madeira. Bragantia, 70: 598-609.

Costa, M.L.; Kern, D.C. 1999. Geochemical signatures of tropical soils with archaeological black earth in the Amazon, Brazil. Journal of Geochemical Exploration, 66: 369-385.

Cunha, T.J.F.; Madari, B.E.; Canellas, L.P.; Ribeiro, L.P.; Benites, V.M.; Santos, G.A. 2009. Soil organic matter and fertility of Anthropogenic Dark Earths (Terra Preta de Índio) in the Brazilian Amazon Basin. Revista Brasileira de Ciência do Solo, 33: 85-93.

Drewry, J.J. 2006. Natural recovery of soil physical properties from treading damage of pastoral soils in New Zealand and Australia: a review. Agriculture, Ecosystem and Environment, 114: 159-169.

Falcáo, N. P. S.; Borges, L.F. 2006. Efeito da fertilidade de terra preta de índio da Amazônia Central no estado nutricional e 
na produtividade do mamão hawaí (Carica papaya L.). Acta Amazonica, 36: 401-406.

Falcão, N.P.S.; Clement, C.R.; Tsai, S.M.; Comerford, N.B. 2009. Pedology, fertility, and biology of Central Amazonian Dark Earths. In: Woods, W.I.; Teixeira, W.G.; Lehmann, J.; Steiner, C.; WinklerPrins, A.M.G.A.; Rebellato, L. (Ed.). Amazonian Dark Earths: Wim Sombroek's Vision. Springer, Berlin. p. 213-228.

Gee, G.W.; Bauder, J.W. 1986. Particle size analysis. p. 383-411. In: Klute, A., ed. Methods of soil analysis. Part I. Physical and mineralogical methods. 2ed. America Society of Agronomy, Madison, WI, USA.

Glaser, B. 2007. Prehistorically modified soils of Central Amazonia: a model for sustainable agriculture in the twenty-first century. Philosophical Transactions of the Royal Society B-Biological Sciences, 362: 187-196.

Glaser, B.; Haumaier, L.; Guggenberger, G.; Zech, W. 2001. The "Terra Preta" phenomenon: a model for sustainable agriculture in the humid tropics. Naturwissenschaften, 88: 37-41.

Hernández-Soriano, M.C. 2012. The Role of Aluminum-Organo Complexes in Soil Organic Matter Dynamics. Soil Health and Land Use Management, InTech, DOI: 10.5772/39117.

Kern, D.C.; Kämpf, N. 1989. O efeito de antigos assentamentos indígenas na formação de solos com terra preta arqueológicas na região de Oriximiná-PA. Revista Brasileira de Ciência do Solo, 13: 219-225.

Lehmann, J.; Kern, D.C.; Glaser, B.; Woods, W.I. 2003. Amazonian Dark Earths: Origin, Properties, Management. Kluwer Academic Publishers, Dodrecht, 505p.

Liang, B.; Lehmann, J.; Solomon, D.; Kinyangi, J.; Grossman, J.; O’Neill, B.; Skjemstad, J.O.; Thies, J.; Luizao, F.J.; Petersen, J.; Neves, E.G. 2006. Black carbon increases cation exchange capacity in soils. Soil Science Society of America Journal, 70: 1719-1730.

Lima, H.N.; Schaeger, C.G.R.; Mello, J.W.V.; Gilkes, R.J.; Ker, J.C. 2002. Pedogenesis and pre-Colombian land use of "Terra Preta Anthsol” (Indian black earth") of Western Amozonia. Geoderma, 100: 1-17.

Mescouto, C.S.T.; Lemos, V.P.; Filho, H.A.D.; da Costa, M.L.; Kern, D.C.; Fernandes, K.G. 2011. Distribution and availability of copper, iron, manganese and zinc in the archaeological black earth profile from the Amazon region. Journal of the Brazilian Chemical Society, 22: 1494-1492.

Moraes, B.C.; Costa, J.M.N; Costa, A.C.L.; Costa, M.H. 2005. Variação espacial e temporal da precipitação no Estado do Pará. Acta Amazonica, 35: 207-214.

Moreira, A.; Teixeira, W.G.; Martins, G.C. 2009. Extratores e disponibilidade de micronutrientes em Terra Preta de Índio da Amazônia Central. Ciencia del suelo, 27: 127-134.
Ritchie, G.S.P. 1995. Soluble aluminum in acidic soils: principles and practicalities. Plant and Soil, 171: 17-27.

Rodrigues, S.F.S. 2014. Os fragmentos de cerâmica arqueológica como fonte potencial de fertilidade dos solos TPA. Tese de doutorado, Universidade Federal do Pará/Instituto de Geociências, Belém, Pará. 141p.

Santos, H.G.; Jacomine, P.K.T.; Anjos, L.H.C.; Oliveira, V.A.; Lumbreras, J.F.; Coelho, M.R.; Almeida, J.A.; Cunha, T.J.F.; Oliveira, J.B. 2013a. Sistema brasileiro de classificação de solos. 3ra ed. Embrapa, Brasília, DF, 353p.

Santos, L.A.C.; Campos, M.C.C.; Aquino, R.E.; Bergamin, A.C.; Silva, D.M.P.; Marques Jr., J.; França, A.B.C. 2013 b. Caracterização de terras pretas arqueológicas no sul do estado do Amazonas. Revista Brasileira de Ciência do Solo, 37: 825-836.

Silveira, M.I.; Oliveira, E.R.; Kern, D.C.; Costa, M.L.; Rodrigues, S.F.S. 2011. O sítio Jabuti, em Bragança, Pará, no cenário arqueológico do litoral amazônico. Boletim do Museu Paraense Emilio Goeldi. Ciências Humanas, 6: 335-345.

Sombroek, W.; Kern, D.C.; Rodrigues, T.; Cravo, M.S.; Jarbas, T.C.; Woods, W.; Glaser, B. 2002. Terra preta and terra mulata: preColumbian Amazon kitchen middens and agricultural fields, their sustainability and their replication. 17th Word Congress of Soil Science, pp. 14-21.

Piccinin, J.L. 2009. Análise estrutural da cobertura pedológica Terra Preta Arqueológica (TPA). Sitio Jabuti-Bragança-PA. Relatório de pesquisa. Museu Paraense Emílio Goeldi, Belém, Pará. 11p.

Teixeira, W.G.; Kern, D.C.; Madari, B.E.; Lima, H.N.; Woods, W. 2009. As Terras Pretas de Índio da Amazônia: sua caracterização e uso deste conhecimento na criação de novas áreas. Embrapa Amazônia Ocidental, Manaus, AM, 422p.

van Genuchten, M. Th. 1980. A closed-form equation for predicting the hydraulic conductivity of unsaturated soils. Soil Science Society of America Journal, 44: 892-898.

Verheijen, F.G.A.; Jeffery, S.; Bastos, A.C.; Van der Velde, M.; Diafas, I. 2010. Biochar Application to Soils: A Critical Scientific Review on Effects on Soil Properties, Processes and Functions. Joint Research Centre (JRC) Scientific and Technical Report, EUR 24099 - EN, Italy.

Woods, W.I.; Teixeira, W.G.; Lehmann, J.; Steiner, C.; WinklerPrins, A.M.G.A.; Rebellato, L. 2009. Amazonian Dark Earths: Wim Sombroek's Vision. 1st ed. Dordrecht:Springer, Berlin. 502p.

Zech, W.; Haumeier, L.; Hempfling, R. 1990. Ecological aspects of soil organic matter in tropical land use. In: MacCarthy, P.; Clapp, C.E.; Malcolm, R.1.; Bloom, P.R. (Ed.). Humic Substances in Soil and Crop Science: Selected Readings. Soil Science Society of America, Madison, p. 187-202.

Recebido em 08/12/2015

Aceito em 26/05/2016 